\title{
The thermal tolerance of crown-of-thorns (Acanthaster planci) embryos and bipinnaria larvae: implications for spatial and temporal variation in adult populations
}

\author{
M. Lamare $\cdot$ D. Pecorino $\cdot$ N. Hardy $\cdot$ \\ M. Liddy $\cdot$ M. Byrne $\cdot$ S. Uthicke
}

Received: 26 August 2013/Accepted: 4 December 2013/Published online: 27 December 2013

(C) The Author(s) 2013. This article is published with open access at Springerlink.com

\begin{abstract}
To understand the role of sea temperature on the population biology of the crown-of-thorns sea star Acanthaster planci, the thermal window for embryonic and larval development was investigated. In two experiments, the response of embryos and larvae across 12 temperatures from 19.4 to $36.5^{\circ} \mathrm{C}$ was quantified as the percentage of individuals reaching cleavage stage embryos, blastula, gastrula, early-bipinnaria, late-bipinnaria larvae or abnormal. Measurements were made at 7 times up to $72 \mathrm{~h}$ postfertilisation, with the morphometrics of larvae measured in the 72-h sample. Acanthaster planci developed at temperatures between 19.4 and $33.2{ }^{\circ} \mathrm{C}$, with a thermal window for development to the late-bipinnaria stage between 25.6
\end{abstract}

Communicated by Biology Editor Dr. Anastazia Banaszak

Electronic supplementary material The online version of this article (doi:10.1007/s00338-013-1112-3) contains supplementary material, which is available to authorized users.

M. Lamare · D. Pecorino

Department of Marine Science, University of Otago,

310 Castle Street, 9016 Dunedin, New Zealand

Present Address:

D. Pecorino

Department for Earth, Environment and Life Sciences

(DISTAV), University of Genoa, Corso Europa 26,

16132 Genoa, Italy

N. Hardy · M. Byrne

Schools of Medical and Biological Sciences, University of Sydney, F13, Anderson Stuart Building, Sydney, NSW 2006, Australia

M. Liddy $\cdot$ S. Uthicke $(\square)$

Australian Institute of Marine Science, PMB 3, Townsville MC,

Townsville, QLD 4810, Australia

e-mail: s.uthicke@aims.gov.au and $31.6{ }^{\circ} \mathrm{C}$. Development rate, normal development and larval size were optimal at $28.7{ }^{\circ} \mathrm{C}$, with development rates remaining relatively constant up to $31.6{ }^{\circ} \mathrm{C}$. Rates of abnormality increased steadily (early embryonic stages) above $28.7^{\circ} \mathrm{C}$ and was $100 \%$ at temperatures approaching $33{ }^{\circ} \mathrm{C}$. These experiments provide a more detailed insight into the response of $A$. planci developmental stages to temperature. The present day distribution of the species in eastern Australia overlap with the optimal thermal window for development to the late-bipinnaria stage $\left(\approx 25-32{ }^{\circ} \mathrm{C}\right)$, implying a role of temperature in controlling population distributions and abundances. Despite this, short- or longterm temperature increases may not be a major modulator of the crown-of-thorns recruitment success, population dynamics and distribution in the future as no significant change in development rates, larval survival and growth occurred within this thermal window. Therefore, moderate $\left(1-2{ }^{\circ} \mathrm{C}\right)$ increases in sea temperatures caused by El Niño or near-future ocean warming may not drive an increase in developmental and settlement success. Indeed, without any acclimation to warmer temperatures expected under nearfuture warming $\left(+2\right.$ to $\left.4{ }^{\circ} \mathrm{C}\right)$, climate change could ultimately reduce larval survival due to elevated mortality above the optimal development temperature.

Keywords Crown-of-thorns - Temperature - Early life stages - Thermotolerance . Thermal window . Climate change

\section{Introduction}

Changes in the abundance and distribution of marine species will be an important outcome of near-future increases in sea temperatures (Hoegh-Guldberg and Bruno 2010). 
For instance, coral reefs in Japan have shifted by as much as $14 \mathrm{~km} \mathrm{yr}^{-1}$ towards the north as sea temperatures in the region warm (Yamano et al. 2011). Similarly, Barry et al. (1995) reported an increase in the abundance of southern marine invertebrate species and a decrease in northern species for a site along the Californian coastline. This coincided with an increase in the annual mean shoreline ocean temperature of $0.75^{\circ} \mathrm{C}$ over the $60-\mathrm{yr}$ period between observations.

For marine species with free-living embryos and larvae, changes in survival and growth rates of their developmental stages as a result of ocean warming can drive spatial and temporal population changes. One of the clearest examples of this process is the expansion of the sea urchin Centrostephanus rodgersii as a result of sea temperature warming off coastal south-eastern Australia and Tasmania (Ling et al. 2009). In this region, the southern expansion of the sea urchin is almost certainly the outcome of new regions entering the thermal window of larval development $\left(12-22^{\circ} \mathrm{C}\right.$ ) as winter sea temperatures increase (Ling et al. 2008).

These observations indicate the importance of quantifying the responses of embryos and larvae to temperature when considering regional warming of the ocean under various climate change scenarios. Developmental stages of marine invertebrates are directly influenced by temperature, and within thermal tolerance windows, developmental rate typically increases with warming due to the stimulating effects on physiological rates (Enquist et al. 2003; Brown et al. 2004; Allen et al. 2006). For echinoderm development, faster progression through embryonic and larval stages occurs with, with increased temperature (Hoegh-Guldberg and Pearse 1995; Hardy et al. 2013; Pecorino et al. 2013). For sea stars specifically, increases in developmental rate with increasing temperature has been described for one polar (Hoegh-Guldberg and Pearse 1995; Stanwell-Smith and Peck 1998), four temperate (Hoegh-Guldberg and Pearse 1995; Lee et al. 2004; Villalobos et al. 2006) and one tropical species (Hoegh-Guldberg and Pearse 1995).

Survival of developmental stages may also be temperature-dependent, with reduced survival outside the thermal window as a result of physiological stresses (Roccheri et al. 1986; Hofmann and Somero 1996; Somero 2010; Tomanek 2010). The number of larvae surviving to settlement may also be influenced by increased temperature, where faster developing larvae are exposed for less time to high predation mortality in the plankton (i.e. instantaneous mortality rates $\approx 0.10-0.20 \mathrm{~d}^{-1}$, Rumrill 1990; Lamare and Barker 1999). Shorter larval duration may also reduce dispersion and recruitment, which can enhance local recruitment rates, although this would reduce the capacity to colonise across wider geographical regions (Hedgecock 1986).
Tropical coral reef ecosystems have degraded in recent decades as a result of human over-exploitation, pollution, bleaching, storm damage and outbreaks of the crown-ofthorns sea star (COTS) Acanthaster planci (Pandolfi et al. 2003; Bruno and Selig 2007; De'ath et al. 2012). For example, the Australian Great Barrier Reef (GBR) may have experienced a $50 \%$ reduction in coral cover between 1985 and 2012 (De'ath et al. 2012), with A. planci outbreaks of particular concern (De'ath et al. 2012). In the case of the GBR, a recent assessment of the impact of three stressors (storms, bleaching, A. planci) estimated that predation by $A$. planci accounted for $42 \%$ of the observed loss (De'ath et al. 2012). Outbreaks of the species, characterised by sudden increases in the abundance of adult populations, have been recorded on most Indo-Pacific coral reefs, including the GBR (review Uthicke et al. 2009). The close link between $A$. planci outbreaks and coral cover loss is an outcome of specialised diet of A. planci, which is an exclusively corallivorous sea star that results in a very high predation pressure on coral when population densities increase (Fabricius 2013).

On the GBR, A. planci ossicles can be found in sediment core slices $>2,000$ yrs old, but there is no indication of population outbreaks prior to the 1960s (Fabricius and Fabricius 1992). The prevalence of outbreaks has, however, been well documented over the past half-century (Birkeland 1982; Moran 1986; Lourey et al. 2000; Bellwood et al. 2004; Fabricius et al. 2010), suggesting that it may be a relatively recent phenomena. Such increases in COTS population sizes have been attributed to a number of factors including reductions in predation pressure on juveniles and adults (McCallum 1987; review Fabricius 2013), reduced salinity (Lucas 1973) and increased phytoplankton productivity and biomass favouring larval development (review Uthicke et al. 2009; Fabricius et al. 2010). The link between $A$. planci outbreaks and enhanced larval survival to settlement has been established using evidence from laboratory, field and modelling studies (Fabricius et al. 2010). In this scenario, the eutrophicationdriven increases in phytoplankton production release larvae from food-limited development and subsequently an increase in the number of larvae completing development (Fabricius et al. 2010).

In addition to food levels, temperature can also affect the pace of embryonic and larval development in A. planci (Hoegh-Guldberg and Pearse 1995) and could potentially contribute to increases in larval survival. In this regard, it was shown that larval development was fastest at temperatures of $\approx 28{ }^{\circ} \mathrm{C}$ (Henderson and Lucas 1971; Lucas 1973). A more comprehensive study of the response of $A$. planci larvae to temperature by Johnson and Babcock (1994) found similar results for the development pace and a narrowing of the temperature tolerance window for 
development of $\approx 1{ }^{\circ} \mathrm{C}$ between gastrula and bipinnaria. Confirming the suggestion of a thermal window for $A$. planci, Hoegh-Guldberg and Pearse (1995) examined the time required to reach hatching noting development rate increased between 20 and $32{ }^{\circ} \mathrm{C}$, with a break at $25^{\circ} \mathrm{C}$.

The contribution of development thermal windows to the distribution of adult sea stars is an important consideration. Lucas (1973) and Johnson and Babcock (1994) discussed the relationship between temperature tolerance and the distribution of $A$. planci around Australia. Lucas (1973) suggested that the southern distribution of $A$. planci is limited by intolerance of the larval stages to temperatures less than $27^{\circ} \mathrm{C}$, although Johnson and Babcock (1994) noted A. planci occurs in regions (namely Lord Howe Island) where maximum summer temperatures at the time of spawning are $\approx 24{ }^{\circ} \mathrm{C}$. Johnson and Babcock (1994) also pointed out that $A$. planci outbreaks initiate in the northern GBR, where sea temperature may be closer to the optimum for development, and fewer smaller outbreaks occur in the cooler southern part of the range.

In this study, we hypothesise that spatial and temporal variability in Acanthaster planci populations may be determined by the thermal tolerance of developmental stages and that warming sea temperatures may alter the population biology of the sea star through changes in early development rates and survival. To test this hypothesis, we determined the thermal window of $A$. planci developmental stages. This was achieved by examining the response of $A$. planci larvae to temperature across a 12-step thermal gradient ranging from 19 to $37^{\circ} \mathrm{C}$. Across this temperature gradient, we examined the pace of development, abnormal development rates and larval morphometrics after $72 \mathrm{~h}$. Using these observations, we firstly re-examine the relationship between larval thermal windows and distributions of $A$. planci, and secondly, we contemplate the potential effects of increases in sea surface temperatures of $2-4{ }^{\circ} \mathrm{C}$ that are predicted to occur along eastern Australia over the coming century (Hobday and Lough 2011).

\section{Methods}

Specimen collection and spawning

Twenty Pacific (sensu Vogler et al. 2008) adult Acanthaster planci were collected by SCUBA divers in early November 2012 from Green Island (GBR, Australia, $16^{\circ} 46.5^{\prime} \mathrm{S}, 145^{\circ} 59.3^{\prime} \mathrm{E}$, Fig. 1) at a depth of 6-12 m, placed in containers with flow-through seawater, and transported to the Australian Institute of Marine Science (Cape Ferguson, North Queensland). There, specimens were kept in seawater tanks provided with running unfiltered seawater at the ambient seawater temperature of $27-28{ }^{\circ} \mathrm{C}$. Biopsies were performed for sex determination, and males and females separated until spawning.

For each experiment, a small $(\approx 1 \mathrm{~cm})$ incision was made near the proximal end of one of the arms of three males and three females and three to four lobes from the gonads were removed from each individual. Testes were placed in Petri dishes and covered in Parafilm ${ }^{\mathrm{TM}}$ to prevent desiccation. Ovarian lobes were rinsed of loose eggs with filtered seawater and were then submerged in a $10^{-5} \mathrm{M}$ 1 -methyladenine in seawater solution to induce egg maturation and egg release. After $2 \mathrm{~h}$, released eggs were pooled to make a stock egg suspension (concentration of 500 eggs $\mathrm{mL}^{-1}$ ). The eggs were transferred to $30 \mathrm{~mL}$ vials filled with filtered seawater to give a final egg density of 20 eggs $\mathrm{mL}^{-1}$. Fertilisation was achieved in the vials (see section 'Experimental design') by adding sperm at a sperm:egg ratio of 100:1 (i.e. 2,000 sperm $\mathrm{mL}^{-1}$ ). After fertilisation, excess sperm was removed by replacing

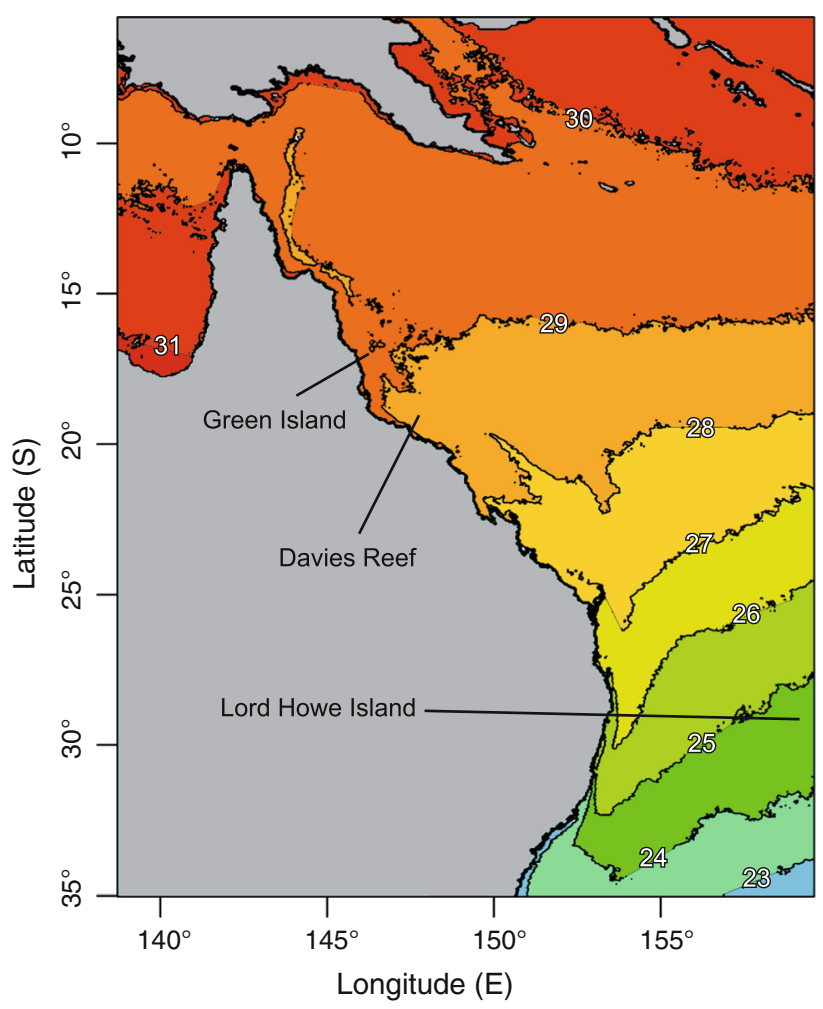

Fig. 1 Map or eastern Australia showing location of the collection site (Green Island), and other locations mentioned in the text (Davies Reef and Lord Howe Island). Site locations are overlaid on earlysummer (November-December) sea surface temperature around eastern Australia (latitude from $5^{\circ} 48.3^{\prime} \mathrm{S}$ to $35^{\circ} 00^{\prime} \mathrm{S}$, longitude from $138^{\circ} 48.5^{\prime} \mathrm{E}$ to $159^{\circ} 36.8^{\prime} \mathrm{E}$ ) averaged across years from 2003 to 2013 . Temperatures are recorded from the SST probe of the satellite Terra MODIS at a resolution of $4 \mathrm{~km}$. Isotherms are at $1{ }^{\circ} \mathrm{C}$ intervals. The months examined coincide with the yearly period of maximum spawning activity of Acanthaster planci in the region 
one-third of the seawater from each experimental vial with water at the appropriate temperature.

\section{Experimental design}

Two thermal window experiments were performed using the same experimental setup. Two aluminium thermal blocks (length $=784 \mathrm{~mm}$, height $=60 \mathrm{~mm}$, width $=170 \mathrm{~mm}$; Pecorino et al. 2013) with twelve holes (diameter $=31 \mathrm{~mm}$, depth $=54 \mathrm{~mm}$ ) in four rows were used. To achieve a thermal gradient in the aluminium blocks from $\approx 19$ to $37{ }^{\circ} \mathrm{C}$, heated or cooled water from temperature-controlled water baths was pumped through the opposite ends of the heat blocks. Each hole in the block held a 30-mL glass vial containing the egg suspension. The six central rows were used as experimental treatments, and the two outer rows were used as a reservoir of filtered seawater at the appropriate experimental temperatures. In total, there were twelve temperature treatments $(19.4,20.3,22.2,24.0,25.6,27.2$, 28.7, 30.2, 31.6, 33.2, 34.8 and $36.5^{\circ} \mathrm{C}$ ), each replicated six times. Lids were placed on each vial during the experiment to prevent evaporation. Temperature was checked at the beginning and at the end of the experiments in the actual experimental vials, and, in both cases, fluctuations within each treatment group over time were minimal $\left(<0.2^{\circ} \mathrm{C}\right)$. Water was replaced in each vial after each sampling time with the same amount of seawater at the appropriate experimental temperature to prevent oxygen depletion. A previous experiment in the same setup (Hardy et al. 2013) indicated that oxygen depletion did not occur using frequency water changes as applied here. All seawater had previously been filtered to $0.5 \mu \mathrm{M}$ to reduce organic and particular load.

At each sampling point, a $2 \mathrm{~mL}$ aliquot was sampled from each vial after gently mixing by inversion. For experiment 1 , sampling times were 5, 10 and $24 \mathrm{~h}$ after fertilisation, and for experiment 2, sampling times were 16 , 24, 48 and $72 \mathrm{~h}$ after fertilisation. Samples were placed in 2-mL Eppendorf ${ }^{\mathrm{TM}}$ tubes and fixed immediately with 2 drops of $7 \%$ borax-buffered formalin. Samples were later checked under a dissection microscope and the number of embryos and larvae in each of six developmental stages, namely, cleavage stage embryos, hatched blastula, gastrula, early-bipinnaria and late-bipinnaria recorded. At least 50 embryos or larvae were scored for each sample. We also recorded the number of abnormal embryos, defined as individuals that displayed an asymmetrical shape, exogastrulation, the presence of a compact cell agglomerate in the coelom or the lack of any of the basic morphological feature of a bipinnaria (e.g. lobes, well-formed gut), depending on developmental stage.

The number in each developmental stage was reported as a percentage of the total number of embryos or larvae scored. For the second experiment, photomicrographs of 10 larvae from each experimental vial at the last sampling time $(72 \mathrm{~h})$ were taken and six body dimensions were measured (aboral hood, oral hood, body length, body width, stomach width, stomach length; Fig. 2), after appropriate calibration, using the software ImageJ (Schneider et al. 2012).

Sea surface temperatures

November to December is the major period of spawning of Acanthaster planci (Babcock and Mundy 1992). Therefore, the average sea surface temperature (SST) measurements during both months over an 11-yr time frame (2003-2013) were collected from the SST probe of the satellite Terra MODIS (http://oceancolor.gsfc.nasa.gov/) from southern Papua New Guinea to just south of the Lord Howe Islands (latitude from $5^{\circ} 48.3^{\prime} \mathrm{S}$ to $35^{\circ} 00^{\prime} \mathrm{S}$, longitude from $138^{\circ} 48.5^{\prime} \mathrm{E}$ to $159^{\circ} 36.8^{\prime} \mathrm{E}$ ) at a resolution of $4 \mathrm{~km}$. The area chosen roughly corresponds to the present day geographical range of $A$. planci in the West-Pacific Ocean. These data were then plotted as a coloured map with highlighted isotherms at $1{ }^{\circ} \mathrm{C}$ intervals (Fig. 1). Water temperature at the sampling date of the spawners $(07 / 11 / 12)$ on Green Island was $27{ }^{\circ} \mathrm{C}$ (C. Collier, pers comm).

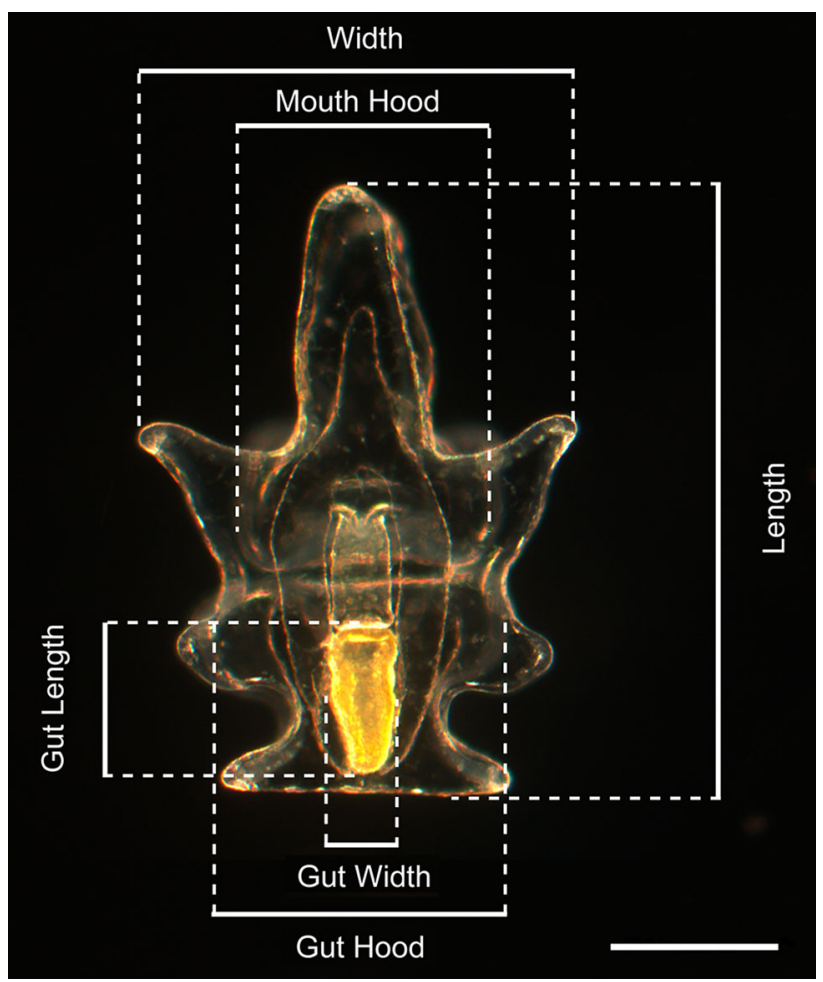

Fig. 2 A 72-h-old bipinnarian Acanthaster planci larvae showing six body components measured in this study: body length (Length), body width (Width), gut width, gut length, oral hood width (Mouth Hood) and aboral hood width (Gut Hood). Scale bar $100 \mu \mathrm{m}$ 
Statistical analyses

The percentages of each developmental stage and abnormal embryos at each given time were arcsine-square root transformed, and significance of the differences in the proportion of larvae at that stage among temperatures was tested using one-way ANOVA (one analysis for each developmental stage at each sampling time), after checking that the assumptions of normality and homoscedasticity were met. Differences between pairs of temperature treatments were then checked using Tukey's HSD test. Morphological data were square root transformed and analysed using principal component analysis (PCA) to identify the body dimensions that most contribute to the difference in morphology of the larvae. A PERMANOVA was performed on the morphological data with the software PERMANOVA for Primer (Anderson et al. 2008) to test for a significant effect of temperature on the global morphology of larvae. Temperature was used as a fixed factor with 12 levels corresponding each to temperature treatment. There were six response variables corresponding to the six aforementioned morphological measurements taken on each larva.

\section{Results}

\section{Experiment 1}

The effect of temperature on the percentage of cleavage stage embryos, hatched blastulae, gastrulae and on the percentage of abnormal embryos was significant at all sampling times (Table 1), and most treatments were significantly different from each other (Electronic Supplementary Material, ESM Table 1). At $5 \mathrm{~h}$, the highest percentage of cleavage stage embryos (Fig. 3a) was recorded between 24.0 and $33.2{ }^{\circ} \mathrm{C}$ (39-78.9\% cleavage across temperatures), with the maximum percentage of cleavage stage embryos (78.9\%) occurring at $28.7{ }^{\circ} \mathrm{C}$. No developing embryos were recorded at temperatures $>33.2{ }^{\circ} \mathrm{C}$ and $<20 \%$ at 19.4, 20.3 and $22.2{ }^{\circ} \mathrm{C}$. At $10 \mathrm{~h}$ (Fig. 3a), most embryos in the 24.0 and $31.6{ }^{\circ} \mathrm{C}$ treatments had divided, while $<20 \%$ had cleaved at 22.2 and $33.2{ }^{\circ} \mathrm{C}$. The embryos at lower or higher temperatures had not developed. After $24 \mathrm{~h}$ (Fig. 3a), cleavage stage embryos (always $<20 \%$ ) were recorded between 22.2 and $31.6{ }^{\circ} \mathrm{C}$, with the percentage decreasing with increasing temperature, and maximum number of cleavage stage embryos remaining $\left(19.7 \%\right.$ ) occurring at $22.2{ }^{\circ} \mathrm{C}$. At $24 \mathrm{~h}$, an opposite trend in the percentage of hatched embryos was found between 22.2 and $31.6{ }^{\circ} \mathrm{C}$, with the percentage increasing with increasing temperature. The percentage of hatched embryos that had not yet undergone gastrulation was $\approx 15 \%$ for all the temperature treatments, apart from $28.7^{\circ} \mathrm{C}$, where it was $21.6 \%$. The highest percentage of gastrulae staged embryos was recorded between 27.2 and $30.2{ }^{\circ} \mathrm{C}$ (33.4-41.7\% across this temperature range), with fewer present at $24.0{ }^{\circ} \mathrm{C}(9.8 \%), 25.6{ }^{\circ} \mathrm{C}(19.4 \%)$ and $31.6^{\circ} \mathrm{C}(5.7 \%)$. No gastrulae were found at other temperatures.

The percentage of abnormal embryos (Fig. 3b) after $5 \mathrm{~h}$ followed an opposite pattern to the percentage of hatching. Most abnormal embryos were found at temperatures $\leq 22.2{ }^{\circ} \mathrm{C}$ ( $>86.4 \%$ of abnormal embryos) and $\geq 34.8^{\circ} \mathrm{C}$ (100\% of abnormal embryos). At temperatures between this range, the percentage of abnormal embryos was between 23 and $64.2 \%$, with the minimum number of abnormal embryos at $28.7^{\circ} \mathrm{C}(23.1 \%)$. A similar pattern was found at 10 and $24 \mathrm{~h}$ after fertilisation, the only notable difference being an increase in the percentage of abnormal individuals at $31.6{ }^{\circ} \mathrm{C}$ (from 29.5 to $80.4 \%$ ) and at $33.2{ }^{\circ} \mathrm{C}$ (from 64.2 to $100 \%)$.

Table 1 ANOVA of the percentage of cleaved embryos, hatched blastulae, gastrulae, early-bipinnaria, late-bipinnaria and abnormal embryos of Acanthaster planci from Green Island (Great Barrier Reef, Australia) among 12 temperature treatments. Sampling times in experiment 1 are denoted by A, and sampling times in experiment 2 are denoted by $\mathrm{B}$

\begin{tabular}{llrl}
\hline Sampling time (h) & Developmental stage & $F$ ratio & $p$ value \\
\hline 5 A & Cleaved embryos & 92.01 & $<0.001$ \\
& Abnormal & 77.63 & $<0.001$ \\
10 A & Cleaved embryos & 523.48 & $<0.001$ \\
& Abnormal & 117.18 & $<0.001$ \\
& Cleaved embryos & 59.58 & $<0.001$ \\
& Hatched blastulae & 46.00 & $<0.001$ \\
& Gastrulae & 318.06 & $<0.001$ \\
& Abnormal & 124.92 & $<0.001$ \\
& Cleaved embryos & 49.57 & $<0.001$ \\
& Hatched blastulae & 29.39 & $<0.001$ \\
& Gastrulae & 29.24 & $<0.001$ \\
& Abnormal & 51.89 & $<0.001$ \\
& Cleaved embryos & 24.45 & $<0.001$ \\
& Hatched blastulae & 17.23 & $<0.001$ \\
& Gastrulae & 140.54 & $<0.001$ \\
& Abnormal & 85.01 & $<0.001$ \\
& Gastrulae & 48.75 & $<0.001$ \\
& Early-bipinnaria & 85.85 & $<0.001$ \\
& Late-bipinnaria & 141.28 & $<0.001$ \\
& Abnormal & 109.14 & $<0.001$ \\
& Gastrulae & 54.54 & $<0.001$ \\
& Early-bipinnaria & 30.78 & $<0.001$ \\
& Late-bipinnaria & 242.41 & $<0.001$ \\
& Abnormal & 140.67 & $<0.001$ \\
\hline & Te & & \\
& & & \\
& & &
\end{tabular}

The factor analysed is 'Temperature treatment'. Numerator $d f=11$, denominator $d f=60$ for all the analyses 

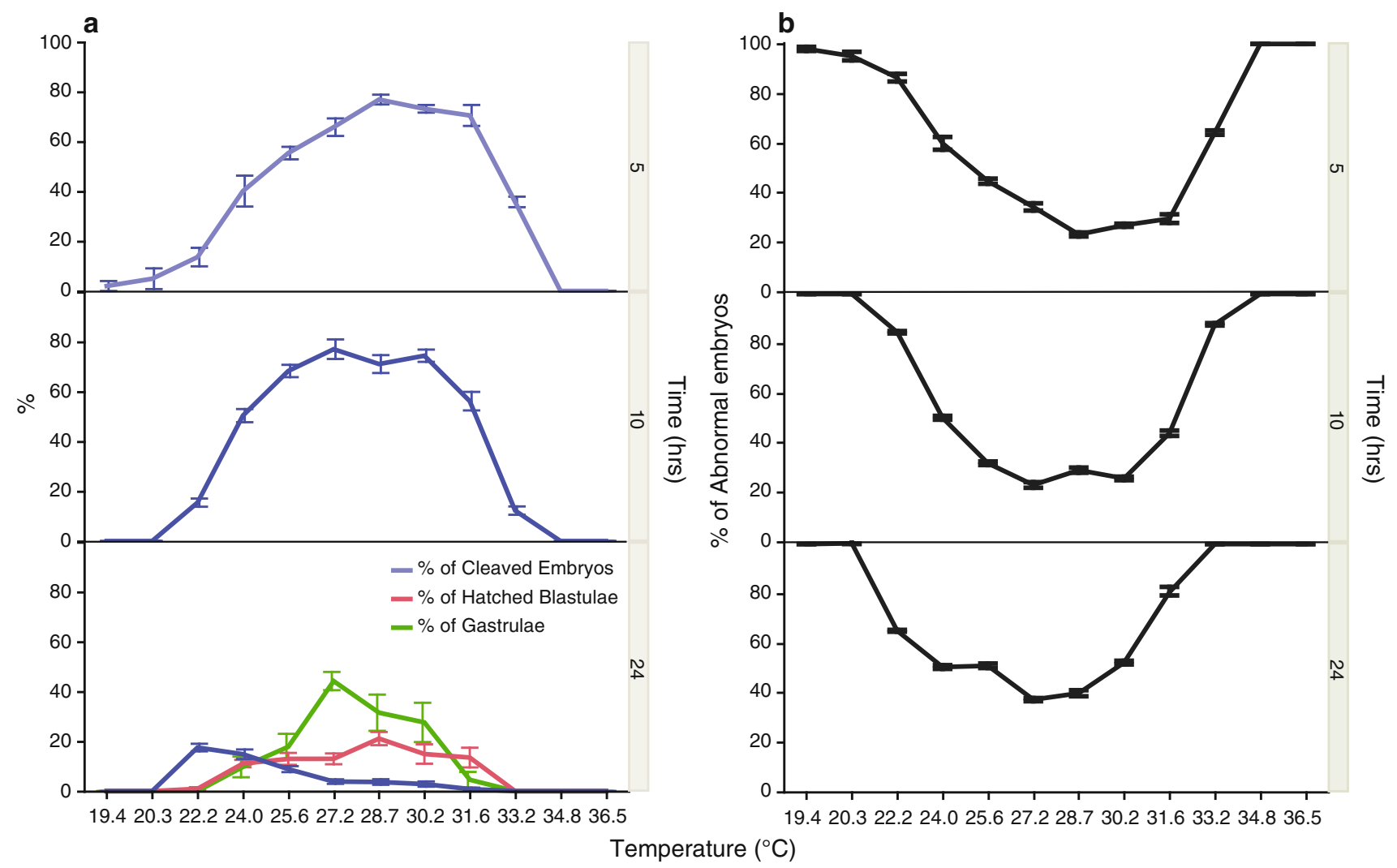

Fig. 3 Percentage of cleavage stage embryos, hatched blastulae, gastrulae, at 5, 10 and $24 \mathrm{~h}$ post-fertilisation for Acanthaster planci at 12 temperature treatments. Points represent mean values \pm standard

\section{Experiment 2}

The influence of temperature on the percentage of cleavage stage embryos, hatched blastulae, gastrulae, early-bipinnaria, bipinnaria and abnormal embryos was significant at all sampling times (Table 1) and most treatments were significantly different from each other (ESM Table 2). At $16 \mathrm{~h}$ after fertilisation (Fig. 4a), cleavage stage embryos, hatched blastulae and gastrulae were recorded. The percentage of unhatched embryos was greatest at $24.0{ }^{\circ} \mathrm{C}$ $(41.3 \%)$. At temperatures lower than $20.3{ }^{\circ} \mathrm{C}$ or higher than $30.2{ }^{\circ} \mathrm{C}$ none of the embryos had hatched. The maximum percentage of hatched blastulae was found at $25.6{ }^{\circ} \mathrm{C}$ $(38.1 \%)$ and $27.2{ }^{\circ} \mathrm{C}(32.6 \%)$ and this sharply decreased towards lower temperatures. No blastulae were found at $<24.0$ and $>33.2{ }^{\circ} \mathrm{C}$, while gastrulae were only recorded between 27.2 and $31.6{ }^{\circ} \mathrm{C}(35.9-61.2 \%$ gastrulae). At $24 \mathrm{~h}$ after fertilisation (Fig. 4a) the proportion of each developmental stage was similar to that seen in Experiment 1 at the same time point. At $48 \mathrm{~h}$ after fertilisation (Fig. $4 \mathrm{a}$ ) gastrulae, early bipinnariae and bipinnariae were present. At the cooler end of the temperature range most embryos error ( $>240$ embryos and larvae were scored across $n=6$ replicate vials for each data point)

had not developed past the gastrula stage (25.0 and $40.3 \%$ at 22.2 and $24.0{ }^{\circ} \mathrm{C}$, respectively). Between 25.6 and $31.6{ }^{\circ} \mathrm{C}$ most of the larvae were bipinnariae (from 31.3 to $64.3 \%$ ). By $72 \mathrm{~h}$ (Fig. 4a) the pattern was similar to $48 \mathrm{~h}$ in terms of developmental stages present and the percentages and temperatures at which they were recorded. One notable difference is that early bipinnariae were recorded at 22.2 and $24.0{ }^{\circ} \mathrm{C}(\approx 10 \%)$ and that bipinnariae were found at $24.0{ }^{\circ} \mathrm{C}(40.4 \%)$.

The percentage of abnormal embryos (Fig. 4b) followed a similar pattern over the $72 \mathrm{~h}$ period. It was $100 \%$ at temperatures $<20.3$ and $>33.2{ }^{\circ} \mathrm{C}$, while at 48 and $72 \mathrm{~h}$ it was $100 \%$ at $20.3{ }^{\circ} \mathrm{C}$. Between 22.2 and $31.6^{\circ} \mathrm{C}$ the percentage of abnormal embryos ranged from $\approx 15$ to $\approx 80 \%$ across the $72 \mathrm{~h}$, with lower rates of abnormality recorded between 25.6 and $30.2{ }^{\circ} \mathrm{C}(15.7-37.8 \%)$.

Larval morphology

The morphology of 72-h bipinnaria varied among temperature treatments, with individuals having a wider gut and a smaller aboral hood the higher the temperature 

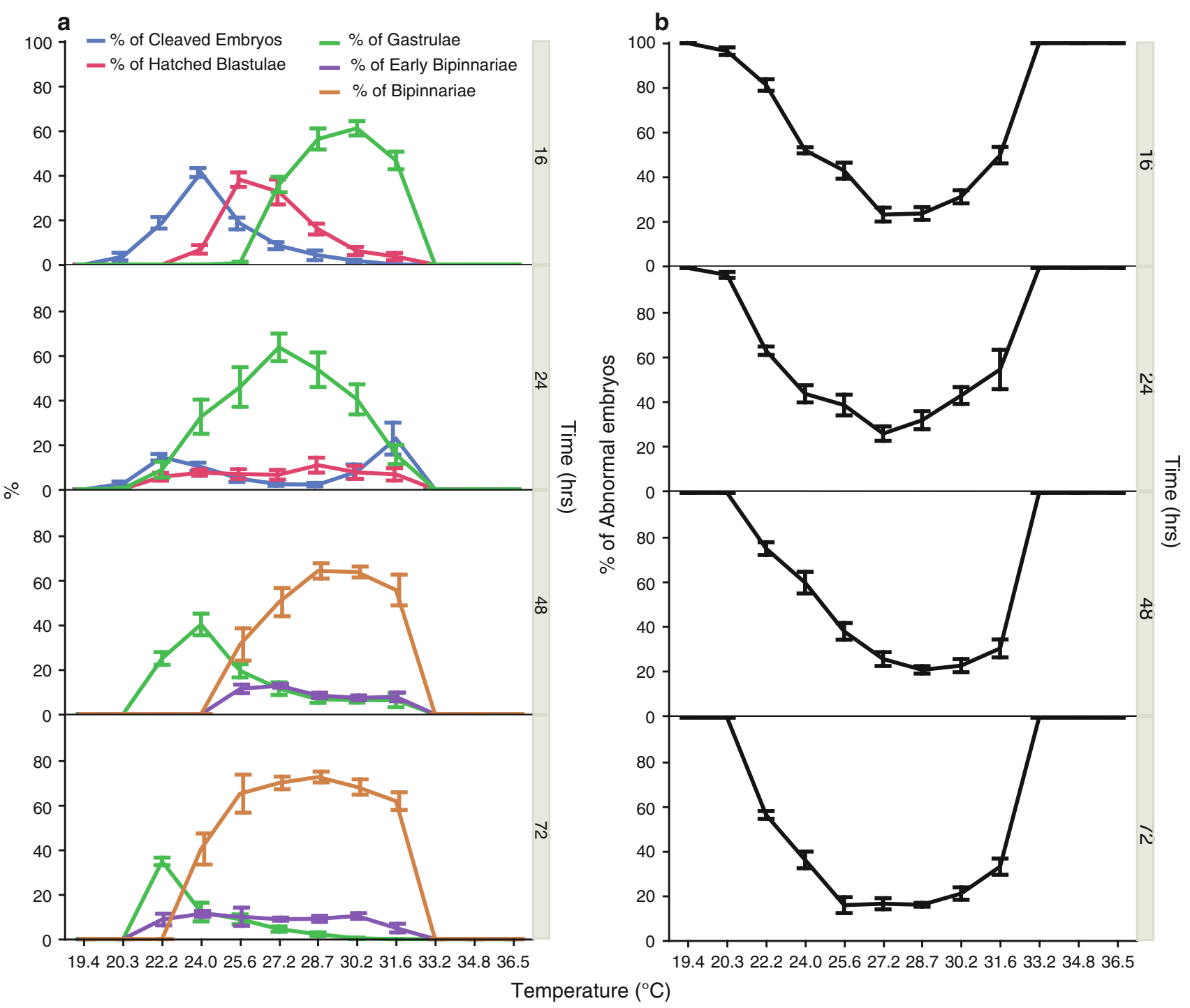

Fig. 4 Percentage of cleavage stage embryos, hatched blastulae, gastrulae, early-bipinnaria larvae, and late-bipinnarian larvae at 16 , 24, 48 and $72 \mathrm{~h}$ post-fertilisation for Acanthaster planci at 12

temperature treatments. Points represent mean values \pm standard error ( $>240$ embryos and larvae were scored across $n=6$ replicate vials for each data point)

Table 2 PERMANOVA on morphological measurements of Acanthaster planci at 12 temperature treatments ranging from 19.4 to $36.5{ }^{\circ} \mathrm{C}$

\begin{tabular}{lrrllr}
\hline Source & $d f$ & \multicolumn{1}{l}{ SS } & MS & Pseudo- $F$ & $p$ (perm) \\
\hline Time & 5 & 664.3 & 132.7 & 7.1 & $<0.001$ \\
Replicate(Time) & 28 & 588.5 & 21 & 2.1 & 0.092 \\
Residuals & 404 & $3,961.5$ & 9.8 & & \\
Total & 437 & $5,256.1$ & & & \\
\hline
\end{tabular}

(Fig. 5). Within the same temperature treatment the shape of the larvae was variable in terms of total larval width and length, gut length and oral hood width, although the effect of temperature on the global morphology of the larvae was significant (Table 2; PERMANOVA Pseudo- $F=7.1303$,

$p$ (perm) <0.001). A subsequent pairwise comparison showed that the difference between larvae at temperature treatments that were not contiguous was significant. In the PCA (Fig. 5), larvae were mostly dispersed along the PC1 axis, which explains $61.7 \%$ or $62.2 \%$ of the total explained variation (ESM Table 3 ) and is negatively correlated with the length and width of the larvae (ESM Table 4). Along this axis, however, there was no clear differentiation based on temperature with significant overlap among the treatments. While comparison of the length and width of larvae among temperatures (Fig. 6a, b) indicated a significant effect of temperature (Table 3; ANOVA on length $F=9.6, p<0.001$; ANOVA on width $F=5.5, p<0.001$ ), the average length and width between 24 and $30.2^{\circ} \mathrm{C}$ were not significantly different (ESM 


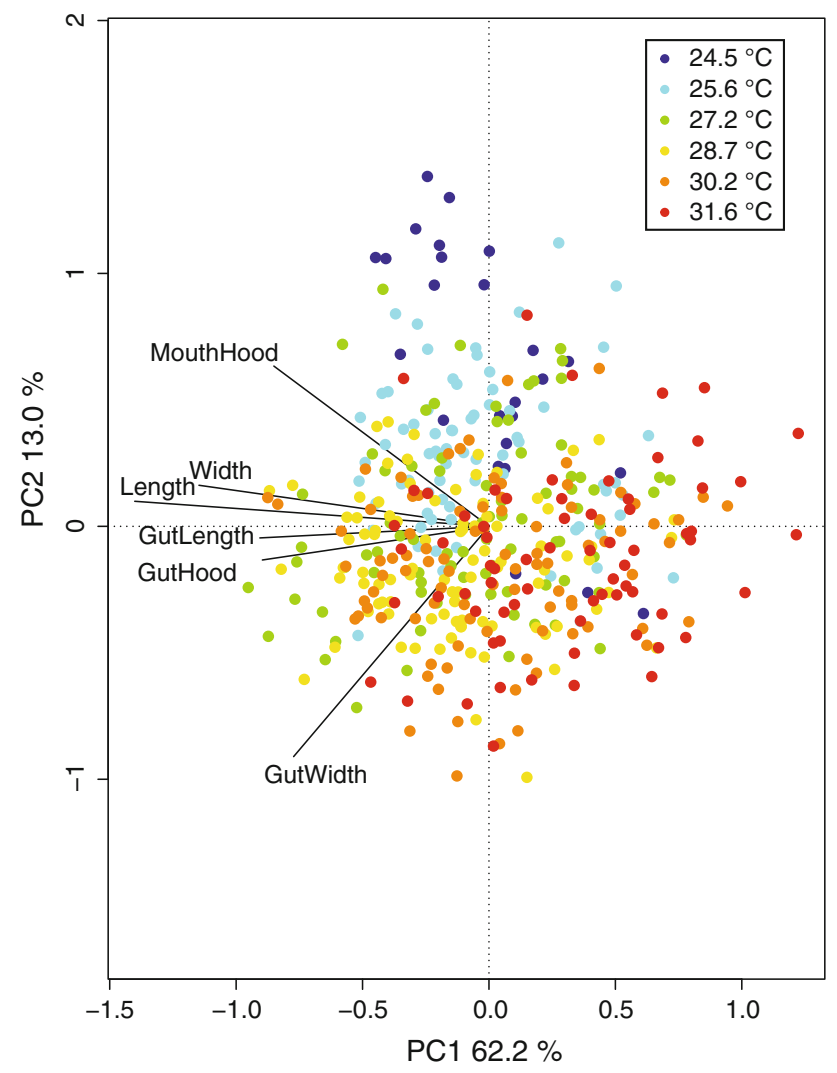

Fig. 5 Plot of the Principal Component Analysis of the morphometrics of 72-h-old Acanthaster planci larvae across 12 temperature treatments. $n=60$ larvae for each temperature

Table 3$)$. Significantly reduced $(\approx 50 \%)$ lengths and widths were only found at $31.6{ }^{\circ} \mathrm{C}$ compared to $30.2{ }^{\circ} \mathrm{C}$ (ESM Table 5).

Sea surface temperature

Average sea surface temperature from November to December (Fig. 1), as derived from satellite data, ranged from $\approx 25{ }^{\circ} \mathrm{C}$ at Lord Howe Islands to $\approx 30{ }^{\circ} \mathrm{C}$ in the southern part of Papua New Guinea. Green Island, Northern Queensland $\left(16^{\circ} 46.5^{\prime} \mathrm{S}, 145^{\circ} 59.3^{\prime} \mathrm{E}\right)$ is located where average sea surface temperature in November and December $\approx 29^{\circ} \mathrm{C}$.

\section{Discussion}

Response of Acanthaster planci development to temperature

In this study Acanthaster planci developed at temperatures $>19.4{ }^{\circ} \mathrm{C}$ and $<33.2{ }^{\circ} \mathrm{C}$, with an optimal thermal window for development to the late-bipinnaria stage after $72 \mathrm{~h}$ between $\approx 25.6$ and $31.6{ }^{\circ} \mathrm{C}$. Johnson and Babcock (1994)
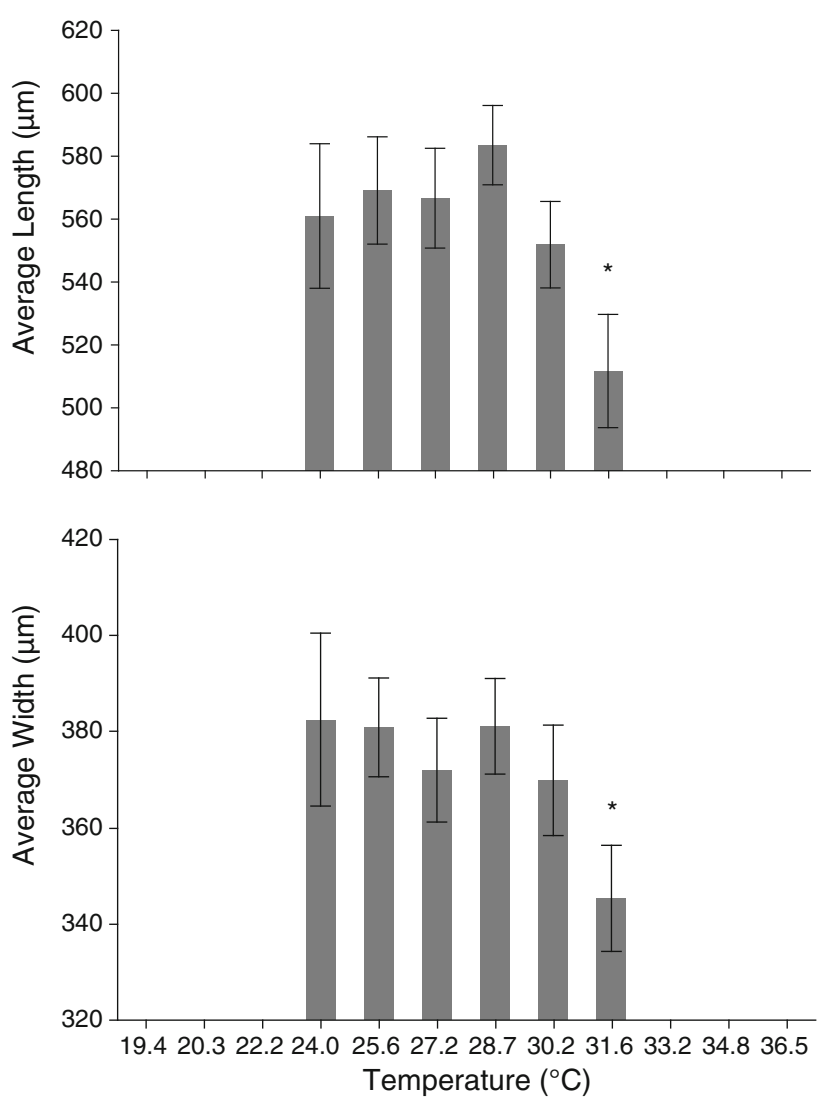

Fig. 6 Average $( \pm$ SE) larval length and larval width in 72-h-old Acanthaster planci larvae across 12 temperature treatments. An asterisk indicates significant differences among temperature treatments. $n=60$ larvae for each temperature

Table 3 ANOVA of the length and width of 72-h-old bipinnariae of Acanthaster planci from Green Island (Great Barrier Reef, Australia) among 12 temperature treatments

\begin{tabular}{lllll}
\hline Dimension & SS & MS & $F$ & $p$ \\
\hline Width & 229,725 & 45,945 & 9.6 & $<0.001$ \\
Length & 66,623 & $13,324.6$ & 5.5 & $<0.001$ \\
\hline
\end{tabular}

The factor analysed is 'Temperature treatment'. Numerator $d f=5$, denominator $d f=60$ for all the analyses

proposed for Acanthaster planci, a thermal tolerance range of $18-31^{\circ} \mathrm{C}$ during the gastrula and bipinnaria stages, and a much narrower window in brachiolaria and competent larvae of $27-31{ }^{\circ} \mathrm{C}$. This later observation was based on earlier work by Lucas (1973) who further suggested that the distribution of the species would be limited to waters warmer than $27^{\circ} \mathrm{C}$.

A narrowing in the thermal window during development was also apparent in our experiments. We base this on the observations that at $5 \mathrm{~h}$ post-fertilisation, the optimal temperatures for early embryonic development were 25.6 and $31.6{ }^{\circ} \mathrm{C}$ (i.e. $>50 \%$ cleavage staged embryos, abnormality 
rate $<50 \%$ ), but if development to gastrula, incorporating both the early and later-embryonic stages is considered, then the optimal temperature range is narrower. For example, at $16 \mathrm{~h}$ post-fertilisation, the greatest percentage $(>50 \%)$ of gastrula occurred between 28.7 and $31.6^{\circ} \mathrm{C}$, with minimum abnormality $(<50 \%)$ occurring between 25.6 and $31.6{ }^{\circ} \mathrm{C}$. A similar optimal thermal window for early-bipinnaria stages was evident at $48 \mathrm{~h}$, implying a constant thermal window through the gastrula and early-bipinnaria stages. Interestingly, at $72 \mathrm{~h}$, there was a broadening of optimal thermal window to $25.6-31.6{ }^{\circ} \mathrm{C}$ for the presence of latebipinnaria, which may indicate bipinnaria develop equally well across a wider temperature range. It could also reflect a general slowing of development during the bipinnaria stages allowing an accumulation of late-bipinnaria at $72 \mathrm{~h}$.

Thermal windows in echinoderm larvae are most widely examined in echinoids and typically have a breadth of $\approx 6-7{ }^{\circ} \mathrm{C}$ (review by Byrne 2011; Pecorino et al. 2013). For asteroids, in addition to Acanthaster planci, the response of embryos and larvae to temperature has been quantified in two polar Odontaster species and a temperate species Asterias miniata (Hoegh-Guldberg and Pearse 1995; StanwellSmith and Peck 1998). In the present study, the thermal window is best described as a flat normal distribution of development rates, with an optimal temperature for development rate, normal development, and larval size in the $28.7^{\circ} \mathrm{C}$ treatment. With decreasing temperatures, development rates slow, with no development occurring below $\approx 20{ }^{\circ} \mathrm{C}$, following a pattern of slowing development rates with decreasing temperatures already reported in literature (Hoegh-Guldberg and Pearse 1995). This relationship between temperature and development (the slope of which appear to be the same within and among echinoderm species) has been interpreted as a lack of temperature compensation in echinoderm developmental processes (Hoegh-Guldberg and Pearse 1995). Hoegh-Guldberg and Pearse (1995) described an exponential reduction in hatching rates and development rate in A. planci and predicted a temperature at which develop would cease at $18.1^{\circ} \mathrm{C}$. In our experiments, development was negligible at $19.4{ }^{\circ} \mathrm{C}$, while Johnson and Babcock (1994) noted cleavage was absent at $18{ }^{\circ} \mathrm{C}$, suggesting that $18-19{ }^{\circ} \mathrm{C}$ represents the species lower thermal limit of the embryonic development.

At temperatures above the optimum, development rates in A. planci remained relatively constant, while rates of abnormality increased. The observation that embryonic and early-larval development rates were independent of temperature across an optimal range has been documented for echinoderm larvae (Stanwell-Smith and Peck 1998; Pecorino et al. 2013). In four sea star species, Hoegh-Guldberg and Pearse (1995) compared development rate and temperature using Arrhenius plots and noted a strong positive effect of temperature on the developmental rate up to a break point value, after which it exerts a small affect on development. In the case of $A$. planci, their calculated break point occurred at $\approx 25{ }^{\circ} \mathrm{C}$, which is consistent with our observation that development to the late-bipinnaria stage at $72 \mathrm{~h}$ plateaued across temperatures between 25.6 and $31.6{ }^{\circ} \mathrm{C}$. Similarly, our findings of no significant differences in total larval length and width between 24 and $30.2{ }^{\circ} \mathrm{C}$ would suggest development is similar across these temperatures. Johnson and Babcock (1994) also reported that $A$. planci larvae developed equally well at 31, 27 and $24{ }^{\circ} \mathrm{C}$, but did not comment on the pace of development at cooler temperatures apart from noting normal larvae were produced.

\section{Response of larvae to oxygen concentration}

Dissolved oxygen concentration is a function of water temperature and therefore has the potential to confound our results. In the present experiments, $100 \% \mathrm{O}_{2}$ saturation would range from $7.48 \mathrm{mg} \mathrm{L}^{-1}$ at $19.4{ }^{\circ} \mathrm{C}$ to $5.64 \mathrm{mg} \mathrm{L}^{-1}$ at $36{ }^{\circ} \mathrm{C}$, while the temperature at which we noted reduced survival $\left(28.7^{\circ} \mathrm{C}\right)$ would coincide with a calculated saturated oxygen concentration of $6.37 \mathrm{mg} \mathrm{L}^{-1}$ (Benson and Krause 1984). It is therefore possible that, in addition to the direct affects of temperature on larval development and survival, reduced larval fitness at warmer temperatures may also be a response to lower oxygen concentrations. Previous research has shown that larval development can be inhibited by hypoxia, although at concentrations distinctly lower than experienced in this study. For example, Crassostrea virginica larvae were inhibited at oxygen concentrations $<0.07 \mathrm{mg} \mathrm{L}^{-1}$ for $24 \mathrm{~h}$ (Baker and Mann 1992), while oxygen concentrations of $0.6-1.3 \mathrm{mg} \mathrm{L}^{-1}$ over 60 h delayed Mytilus edulis embryonic and larval development (Wang and Widdows 1991). For the bivalve Mercenaria mercenaria, while survival was not affected, development stopped at $<1.0 \mathrm{mg} \mathrm{O}_{2} \mathrm{~L}^{-1}$ (Morrison 1971). At similar oxygen concentrations $\left(1 \mathrm{mg} \mathrm{O}_{2} \mathrm{~L}^{-1}\right.$ ), polychaete larvae (Hydroides elegans) showed reduced feeding rates and delayed development (Shin et al. 2013). Eerkes-Medrano et al. (2013) examined the response of larvae to low oxygen concentrations in nine invertebrate species, noting sensitivity to hypoxic conditions varied among species and developmental stages. In all cases, however, there was no significance reduction in survival in treatments until oxygen concentrations were reduced below $1.8 \mathrm{~mL} \mathrm{O}_{2} \mathrm{~L}^{-1}$.

Although not extensively studied in marine larvae, it has been suggested that reduced oxygen concentrations slow development through metabolic depression such as reduced ATP turnover (Hochachka 1997) and metabolic adjustment to survive hypoxic conditions ( $\mathrm{Wu} 2002$ ), while abnormal development has been attributed to disruption of histogenesis through altered apoptosis (Shang and Wu 2004). 
Given that the oxygen levels in the present study were never lower than $5.64 \mathrm{mg} \mathrm{O}_{2} \mathrm{~L}^{-1}$ and remained $>90 \%$ saturation between water changes (Hardy et al. 2013), the effects of oxygen concentration may be less important than warming. Indeed, sea star larvae appear to have a high tolerance to hypoxia, with the bipinnaria and brachiolaria larvae of Pisaster ochraceus showing no decrease in survival, even after exposure to near-anoxia conditions $\left(<0.5 \mathrm{~mL} \mathrm{O}_{2} \mathrm{~L}^{-1}\right)$ for up to $6 \mathrm{~d}$ (Eerkes-Medrano et al. 2013). For other marine invertebrate larvae, development was normal when oxygen concentrations remained greater than $3 \mathrm{mg} \mathrm{O}_{2} \mathrm{~L}^{-1}$ (which is lower than the minimum experienced in the present study). For example, Mercenaria mercenaria, eggs developed normally above $0.5 \mathrm{mg} \mathrm{O}_{2} \mathrm{~mL}^{-1}$, while larval growth was normal above $4.2 \mathrm{mg} \mathrm{O}_{2} \mathrm{~L}^{-1}$. For Hydroides elegans larvae, feeding and development was not significantly different between normal $\left(6 \mathrm{mg} \mathrm{O}_{2} \mathrm{~L}^{-1}\right)$ and reduced $\left(3 \mathrm{mg} \mathrm{O}_{2} \mathrm{~L}^{-1}\right)$ oxygen concentrations (Shin et al. 2013).

Thermal windows, temperature tolerances and Acanthaster planci distribution

Our observations give insight into the developmental responses of A. planci larvae to temperature, with development to the late-bipinnaria stages occurring in an optimal thermal window that spans $\approx 25-31{ }^{\circ} \mathrm{C}$. Within this thermal window, development is largely independent of temperature. Our summary contrasts the Johnson and Babcock (1994) model of temperature tolerances in this species that spans from 19 to $31{ }^{\circ} \mathrm{C}$ for development to the late-bipinnaria stage. The distinction between thermal tolerance range (used by Johnson and Babcock 1994) and optimal thermal window (this study) is important; however, as the numbers of larvae reaching settlement is a function of both survival rate and development rate. As instantaneous mortality rates of echinoderm larvae in the plankton are high (i.e. $\mathrm{M} \approx 0.1-0.2 \mathrm{~d}^{-1}$, Rumrill 1990; Lamare and Barker 1999) and generally associated with predation and not physiological stress, then in situ development rates is likely more important determinant of survival to settlement than temperature tolerance.

The distribution of A. planci around Australia occurs at locations where sea surface temperatures in November and December range from $\approx 25$ to $31^{\circ} \mathrm{C}$ (Fig. 1). For example, Benzie (1999) used data for A. planci from 23 localities, with the most southern occurring on Lord Howe Island (December SST $\approx 25{ }^{\circ} \mathrm{C}$, Fig. 1 ) and the most northern in the Gulf of Carpentaria (December SST $\approx 30{ }^{\circ} \mathrm{C}$, Fig. 1). The remaining populations are reported to occur within the GBR where SST in summer range from 26 to $30{ }^{\circ} \mathrm{C}$ (Fig. 1). The distribution of these populations occurs within the optimal thermal window for development to the late-bipinnarian stage that we propose and would be consistent with a suggestion that successful recruitment requires development within the optimal temperature range. Tolerance to cooler temperatures (i.e. $19{ }^{\circ} \mathrm{C}$ ) documented by Johnson and Babcock (1994) does not appear to be a driver of distributions as there are no reports of $A$. planci populations in sea temperatures between 19 and $25^{\circ} \mathrm{C}$. Other factors, however, could influence the absence of A. planci from these cooler areas, such as the strict association of this sea star with coral, its only food source, and which are not found in these colder waters. The relationship between SST, larval thermal windows and adult distributions would not be unique to $A$. planci and occurs in other echinoderm species in the Australasia. For example, Centrostephanus rodgersii in eastern Australia has an optimal thermal window between $\approx 12$ and $20^{\circ} \mathrm{C}$ which has historically restricted the adult populations to waters where winter SST are warmer than $12{ }^{\circ} \mathrm{C}$ (Ling et al. 2009; Hardy et al. 2013; Pecorino et al. 2013). Furthermore, the same sea urchin species occurs in northern New Zealand where adults are restricted to waters where winter SST $>15{ }^{\circ} \mathrm{C}$ which is consistent with the well-defined minimum thermal window $>16{ }^{\circ} \mathrm{C}$ for embryonic and plutei development.

While the distribution of $A$. planci overlaps with the optimal thermal window, we propose the patterns are not consistent with the Johnson and Babcock (1994) model of thermal tolerance that incorporates data from Lucas (1973) for later larval development (i.e. brachiolaria larvae) that restricts development to between 27 and $31{ }^{\circ} \mathrm{C}$. The thermal window of late-staged larvae of A. planci may, in fact, be broader than that reported by Lucas (1973) if the apparent acclimation to temperature observed in this species is considered. For example, Johnson and Babcock (1994) found that larvae derived from individuals collected at two locations (Davies Reef and Gove Peninsula) varied in their response to temperature, with those from warmer locations appearing to have a warmer thermal window, thus supporting the hypothesis of scope for adaptation (see above). In addition, acclimation also appears to occur within populations as sea temperatures change seasonally. In this respect, Johnson and Babcock (1994) noted that larvae from animals collected earlier in the season were less tolerant of warmer temperatures compared with larvae derived from adults later in the season when sea temperatures were $1.5{ }^{\circ} \mathrm{C}$ higher. In the context of the thermal window of the later-staged brachiolaria larvae, those tested by Lucas (1973) were derived from individuals from the warmer part of the species range (GBR reefs around $146^{\circ} 51^{\prime} \mathrm{E}, 18^{\circ} 2^{\prime} \mathrm{S}$, water temperatures $\approx 29^{\circ} \mathrm{C}$ ), and acclimation at these temperature may have meant they were less tolerant of cooler temperatures.

The questions of acclimation to temperature and the thermal window of the advanced larvae need to be 
quantified if the relationship between distributions and larval thermal tolerances is to be fully understood. Indeed, Johnson and Babcock (1994) commented that the thermal tolerances of later-staged larvae should be re-examined, especially for populations in the cooler regions of their distributions. Our experiments using heat blocks (where larvae were reared in small volumes, $30 \mathrm{~mL}$ ) did not allow us to rear the larvae beyond the late-bipinnaria, although unpublished, experiments indicate that rapid development to metamorphosis (16 d) also occurred at $28{ }^{\circ} \mathrm{C}$ (Lucas 1973).

\section{Responses of Acanthaster planci to ocean warming}

Acanthaster planci population abundances undergo significant decadal-scale variation, and these outbreaks have been attributed to either natural fluctuations (Vine 1973), anthropogenic-related increasing in planktonic food supply that enhances larvae survival (Fabricius et al. 2010), or by the removal of juvenile predators (Bradbury and Seymour 1997). Some A. planci outbreaks have also been linked with El Niño events, as they both act as contemporary stressors on corals, causing higher mortality (Glynn 1990; Fong and Glynn 2001). Moreover, higher SST associated with El Niño events could favour A. planci larval survival at the cooler extreme of its distribution. It is interesting therefore to contemplate how increases in sea temperatures may affect $A$. planci abundances and future distributions.

Three observations from our experiments are relevant to this discussion. Firstly, A. planci larvae have a broad optimal thermal window (i.e. $25-31{ }^{\circ} \mathrm{C}$ ), which encompasses the present day distribution of $A$. planci. Within this thermal window, there is no significant change in either development rates, larval survival or growth rates, and therefore, moderate increases in sea temperatures of $1-2{ }^{\circ} \mathrm{C}$ that occur during $\mathrm{El}$ Niño years, or longer-term warming under climate change $\left(2-4^{\circ} \mathrm{C}\right)$ may not directly enhance development rates in the plankton and hence survival to settlement. In fact, without any acclimation or adaptation to warmer temperatures, larval survival would decline if temperatures warm above $31{ }^{\circ} \mathrm{C}$ (the upper thermal limit). Presently, the entire GBR is at optimal temperature during spawning (Fig. 1), and such temperatures could be exceeded in the northern part including our source population, under near-future warming of $+2{ }^{\circ} \mathrm{C}$.

Secondly, if distributions of $A$. planci populations are, in part, related to the larval thermal window, then warming of sea temperatures in the southern range of the species would potentially extend its southern distribution around Australia. Coastal eastern Australia has experienced significant warming over the past half-century (Ridgway 2007) due to the well-documented increase in southerly flow by $350 \mathrm{~km}$ of the EAC (Ridgway 2007), and warm-water species ranges can expand as temperatures become favourable. Finally, it is possible that spawning seasons may shift to encompass optimal temperatures for larvae, as was observed in 5 populations along a latitudinal gradient in Japan (Yasuda et al. 2010).

Our experiments provide a more detailed (but not complete) insight into the response of $A$. planci developmental stages to temperature. We suggest that the present day distributions of the species in Australia broadly overlap with the optimal thermal window to late-bipinnarian development, which also coincides with the distribution of coral reefs. The broad thermal window would suggest that moderate $\left(1-2{ }^{\circ} \mathrm{C}\right)$ increases in sea temperatures such as those during El Niño or near-future ocean warming would not drive an increase in the numbers of larvae surviving to settlement. Similarly, our findings also suggest that a potential poleward spread of coral reefs (Yamano et al. 2011) would also be accompanied by a spread of A. planci. Our observations would therefore support the hypothesis that in situ development and larval survival is principally controlled, not by temperature, but by other factors such as increases in food availability (Fabricius et al. 2010) or during El Niño events. To advance our conclusions, thermal windows for later-staged larvae and region differences in the thermal biology of larvae are required. In addition, other important changes in the region are underway, such as ocean acidification which can be detrimental to echinoderm larvae (Byrne 2011, Byrne et al. 2013a) including asteroid larvae (Gonzalez-Bernat et al. 2012; Byrne et al. $2013 b$ ) and several early life history stages in $A$. planci (Uthicke et al. 2013). The interaction of temperate and ocean $\mathrm{pH}$ needs to be considered in further experimental work.

Acknowledgments We are very grateful to Steve Moon for organising Acanthaster planci collections. Funding was provided by the Australian Institute of Marine Science and the Australian Government's National Environmental Research Program and an Australian Research Council Grant.

Open Access This article is distributed under the terms of the Creative Commons Attribution License which permits any use, distribution, and reproduction in any medium, provided the original author(s) and the source are credited.

\section{References}

Allen AP, Gillooly JF, Savage VM, Brown JH (2006) Kinetic effects of temperature on rates of genetic divergence and speciation. Proc Natl Acad Sci USA 103:9130-9135

Anderson MJ, Gorley RN, Clarke KR (2008) PERMANOVA for Primer. Primer-E Ltd, Plymouth, United Kingdom

Babcock RC, Mundy CN (1992) Reproductive biology, spawning and field fertilization rates of Acanthatser planci. Mar Freshw Res 43:525-533 
Baker SM, Mann R (1992) Effects of hypoxia and anoxia on larval settlement, juvenile growth, and juvenile survival of the oyster Crassostrea virginica. Biol Bull 182:265-269

Barry JP, Baxter CH, Sagarin RD, Gilman SE (1995) Climate-related, long-term faunal changes in a California rocky intertidal community. Science 267:672-675

Bellwood DR, Hughes TP, Folke C, Nyström M (2004) Confronting the coral reef crisis. Nature 429:827-833

Benson BB, Krause D Jr (1984) The concentration and isotopic fractionation of oxygen dissolved in freshwater and seawater in equilibrium with the atmosphere. Limnol Oceanogr 29:620-632

Benzie JAH (1999) Major genetic differences between Crown-ofThorns starfish (Acanthaster planci) populations in the Indian and Pacific Oceans. Evolution 53:1782-1795

Birkeland C (1982) Terrestrial runoff as a cause of outbreaks of Acanthaster planci (Echinodermata: Asteroidea). Mar Biol 69:175-185

Bradbury R, Seymour R (1997) Waiting for COTS. In: Lessios HA, McIntyre IG (eds) Proc 8th Int Coral Reef Symp 2:1357-1362

Brown JH, Gillooly JF, Allen AP, Savage VM, West GB (2004) Toward a metabolic theory of ecology. Ecology 85:1771-1789

Bruno JF, Selig ER (2007) Regional decline of coral cover in the Indo-Pacific: timing, extent, and subregional comparisons. PLoS One 2:e711

Byrne M (2011) Impact of ocean warming and ocean acidification on marine invertebrate life history stages: vulnerabilities and potential for persistence in a changing ocean. Oceanogr Mar Biol Annu Rev 49:1-42

Byrne M, Lamare M, Winter D, Dworjanyn S, Uthicke S (2013a) The stunting effect of a high $\mathrm{CO}_{2}$ ocean on calcification and development in sea urchin larvae, a synthesis from the tropics to the poles. Phil Trans R Soc B: Biol Sci 368(1627):1471-2970

Byrne M, Gonzalez-Bernat M, Doo S, Foo S, Soars N, Lamare M (2013b) Effects of ocean warming and acidification on embryos and non-calcifying larvae of the invasive sea star Patiriella regularis. Mar Ecol Prog Ser 473:235-246

De'ath G, Fabricius KE, Sweatman H, Puotinen M (2012) The 27-year decline of coral cover on the Great Barrier Reef and its causes. Proc Natl Acad Sci USA 109:17995-17999

Eerkes-Medrano D, Menge BA, Sislak C, Langdon CJ (2013) Contrasting effects of hypoxic conditions on survivourship of planktonic larvae of rocky intertidal invertebrates. Mar Ecol Prog Ser 478:139-151

Enquist BJ, Economo EP, Huxman TE, Allen AP, Ignace DD, Gillooly JF (2003) Scaling metabolism from organisms to ecosystems. Nature 423:639-642

Fabricius KE (2013) Acanthaster planci. In: Lawrence JM (ed) Starfish: biology and ecology of the Asteroidea. JHU Press, Maryland, USA, pp 133-152

Fabricius KE, Fabricius FH (1992) Re-assessment of ossicle frequency patterns in sediment cores: Rate of sedimentation related to Acanthaster planci. Coral Reefs 11:109-114

Fabricius KE, Okaji K, De'ath G (2010) Three lines of evidence to link outbreaks of the crown-of-thorns seastar Acanthaster planci to the release of larval food limitation. Coral Reefs 29:593-605

Fong P, Glynn PW (2001) Population abundance and size-structure of an eastern tropical Pacific reef coral after the 1997-98 Enso: a simulation model predicts field measures. Bull Mar Sci 69:187-202

Glynn PW (ed) (1990) Coral mortality and disturbances to coral reefs in the tropical eastern Pacific. In: Global ecological consequences of the 1982-1983 El Nino-southern oscillation. Elsevier Oceanography Series. Elsevier, Amsterdam, pp 55-126

Gonzalez-Bernat MJ, Lamare M, Uthicke S, Byrne M (2012) Fertilisation, embryogenesis and larval development in the tropical intertidal sand dollar Arachnoides placenta in response to reduced seawater $\mathrm{pH}$. Mar Biol 160:1927-1941

Hardy N, Lamare M, Uthicke S, Wolfe K, Doo SS, Dworjanyn S, Byrne M (2013) Thermal tolerance of early development in tropical and temperate sea urchins: inferences for the tropicalisation of eastern Australia. Mar Biol. doi:10.1007/s00227-0132344-z

Hedgecock D (1986) Is gene flow from pelagic larval dispersal important in the adaptation and evolution of marine invertebrates? Bull Mar Sci 39:550-564

Henderson JA, Lucas JS (1971) Larval development and metamorphosis of Acanthaster planci (Asteroidea). Nature 232:655-657

Hobday AJ, Lough JM (2011) Observed climate change in Australian marine and freshwater environments. Mar Freshw Res 62:984-999

Hochachka PW (1997) Oxygen - a key regulatory metabolite in metabolic defense against hypoxia. Am Zool 37:595-603

Hoegh-Guldberg O, Bruno JF (2010) The impact of Climate Change on the world's marine ecosystems. Science 328:1523-1528

Hoegh-Guldberg O, Pearse JS (1995) Temperature, food availability, and the development of marine invertebrate larvae. Am Zool $35: 415-425$

Hofmann GE, Somero GN (1996) Interspecific variation in thermal denaturation of proteins in the congeneric mussels Mytilus trossulus and M. galloprovincialis: evidence from the heat-shock response and protein ubiquitination. Mar Biol 126:65-75

Johnson LG, Babcock RC (1994) Temperature and the larval ecology of the crown-of-thorns starfish, Acanthaster planci. Biol Bull 187:304-308

Lamare MD, Barker MF (1999) In situ estimates of larval development and mortality in the New Zealand sea urchin Evechinus chloroticus (Echinodermata: Echinoidea). Mar Ecol Prog Ser 180:197-211

Lee C-H, Ryu T-K, Choi J-W (2004) Effects of water temperature on embryonic development in the northern Pacific asteroid, Asterias amurensis, from the southern coast of Korea. Invertebr Reprod Dev 45:109-116

Ling SD, Johnson CR, Frusher S, King CK (2008) Reproductive potential of a marine ecosystem engineer at the edge of a newly expanded range. Glob Change Biol 14:907-915

Ling SD, Johnson CR, Ridgway K, Hobday AJ, Haddon M (2009) Climate-driven range extension of a sea urchin: inferring future trends by analysis of recent population dynamics. Glob Change Biol 15:719-731

Lourey MJ, Ryan DA, Miller IR (2000) Rates of decline and recovery of coral cover on reefs impacted by, recovering from and unaffected by crown-of-thorns starfish Acanthaster planci: a regional perspective of the Great Barrier Reef. Mar Ecol Prog Ser 196:179-186

Lucas JS (1973) Reproductive and larval biology of Acanthaster planci (L.) in Great Barrier Reef waters. Micronesica 9:197-203

McCallum HI (1987) Predator regulation of Acanthaster planci. J Theor Biol 127:207-220

Moran PJ (1986) The Acanthaster phenomenon. Oceanogr Mar Biol Annu Rev 24:379-480

Morrison G (1971) Dissolved oxygen requirements for embryonic an larval development of the hardshell clam, Mercenaria mercenaria. J Fish Res Board Can 28:379-381

Pandolfi JM, Bradbury RH, Sala E, Hughes TP, Bjorndal KA, Cooke RG, McArdle D, McClenachan L, Newman MJH, Paredes G, Warner RR, Jackson JBC (2003) Global trajectories of the longterm decline of coral reef ecosystems. Science 301:955-958

Pecorino D, Lamare MD, Barker MF, Byrne M (2013) How does embryonic and larval thermal tolerance contribute to the distribution of the sea urchin Centrostephanus rodgersii (Diadematidae) in New Zealand? J Exp Mar Biol Ecol 445:120-128 
Ridgway KR (2007) Long-term trend and decadal variability of the southward penetration of the East Australian Current. Geophys Res Lett 34:L13613

Roccheri MC, Sconzo G, La Rosa M, Oliva D, Abrignani A, Giudice G (1986) Response to heat shock of different sea urchin species. Cell Differ 18:131-135

Rumrill SS (1990) Natural mortality of marine invertebrate larvae. Ophelia 32:163-198

Schneider CA, Rasband WS, Eliceiri KW (2012) NIH image to imageJ: 25 years of image analysis. Nat Methods 9(7):671-675

Shang EHH, Wu RSS (2004) Aquatic hypoxia is a teratogen and affects fish embryonic development. Environ Sci Technol 38:4763-4767

Shin PKS, Leung JYS, Qiu JW, Ang PO, Chiu JMY, Thiyagarajan V, Cheung SG (2013) Hypoxia induces abnormal larval development and affects biofilm-larval interaction in the serpulid polychaete Hydroides elegans. Mar Pollut Bull 76:291-297

Somero GN (2010) The physiology of climate change: how potentials for acclimatization and genetic adaptation will determine "winners" and "losers". J Exp Biol 213:912-920

Stanwell-Smith D, Peck LS (1998) Temperature and embryonic development in relation to spawning and field occurrence of larvae of three Antarctic echinoderms. Biol Bull 194:44-52

Tomanek L (2010) Variation in the heat shock response and its implication for predicting the effect of global climate change on species' biogeographical distribution ranges and metabolic costs. J Exp Biol 213:971-979

Uthicke S, Schaffelke B, Byrne M (2009) A boom-bust phylum? Ecological and evolutionary consequences of density variations in echinoderms. Ecol Monogr 79:3-24
Uthicke S, Pecorino D, Albright R, Negri AP, Cantin N, Liddy M, Dworjanyn S, Kamya P, Byrne M, Lamare M (2013) Impacts of ocean acidification on early life-history stages and settlement of the coral-eating sea star Acanthaster planci. PLoS One 8:e82938

Villalobos FB, Tyler PA, Young CM (2006) Temperature and pressure tolerance of embryos and larvae of the Atlantic seastars, Asterias rubens and Marthasterias glacialis (Echinodermata: Asteroidea): potential for deep-sea invasion. Mar Ecol Prog Ser 314:109-117

Vine PJ (1973) Crown of thorns (Acanthaster planci) plagues: the natural causes theory. Atoll Res Bull 166:1-10

Vogler C, Benzie J, Lessios H, Barber P, Woerheide G (2008) A threat to coral reefs multiplied? Four species of crown-of-thorns starfish. Biol Lett 4:696-699

Wang WX, Widdows J (1991) Physiological responses of mussel larvae Mytilus edulis to environmental hypoxia and anoxia. Mar Ecol Prog Ser 70:223-236

Wu RSS (2002) Hypoxia: from molecular responses to ecosystem responses. Mar Pollut Bull 45:35-45

Yamano H, Sugihara K, Nomura K (2011) Rapid poleward range expansion of tropical reef corals in response to rising sea surface temperatures. Geophys Res Lett 38:L04601

Yasuda N, Ogasawara K, Kajiwara K, Ueno M, Oki K, Taniguchi H, Kakuma S, Okaji K, Nadaoka K (2010) Latitudinal differentiation in the reproduction patterns of the crown-of-thorns starfish Acanthaster planci through the Ryukyu Island Archipelago. Plankton Benthos Res 5:156-164 